\title{
PENANGKAPAN SISTEM NGESAR (ACTIVE SEINE) DI PERAIRAN DAERAH ALIRAN SUNGAI MUSI, SUMATERA SELATAN
}

\author{
Azwar Said') dan Andri Warsa') \\ 1) Peneliti pada Balai Riset Perikanan Perairan Umum, Mariana-Palembang \\ 2) Peneliti pada Loka Riset Pemacuan Stok Ikan, Jatiluhur-Purwakarta \\ Teregristrasi I tanggal: 28 Pebruari 2007; Diterima setelah perbaikan tanggal: 21 Mei 2007; \\ Disetujui terbit tanggal: 21 Nopember 2007
}

\begin{abstract}
ABSTRAK
Daerah aliran Sungai Musi merupakan salah satu sungai terpanjang dan terbesar di Sumatera dengan panjang mencapai $\pm 510 \mathrm{~km}$ yang meliputi wilayah hulu (upper stream), wilayah tengah (middle stream), dan wilayah hilir (lower stream). Pada wilayah tengah banyak terdapat rawa banjiran (flood plain). Ngesar adalah kegiatan untuk menangkap ikan yang telah terkonsentrasi baik di sungai maupun di rawa lebak pada puncak musim kemarau atau air surut dengan menggunakan alat bantu berupa arat atau karakat dari jaring (seine) dan pagar bambu atau empang (barrier) sebagai perangkap atau rumah ikan. Ikan yang didapat berjumlah 28 jenis dan yang dominan adalah baung (Mystus nemurus), gabus (Channa striata), lais (Cryptopterus sp.), sapil (Helostoma spp.), tembakang (Helostoma temminckii), dan toman (Channa micropeltes).
\end{abstract}

KATAKUNCI: daerah aliran Sungai Musi, rawa banjiran, penangkapan, ngesar, ikan

\section{PENDAHULUAN}

Daerah aliran Sungai Musi merupakan salah satu sungai terpanjang dan terbesar di Sumatera dengan panjang mencapai $\pm 510 \mathrm{~km}$ yang terdiri atas wilayah hulu (upper stream), wilayah tengah (middle stream), dan wilayah hilir (lower stream). Pada wilayah tengah banyak terdapat rawa banjiran (flood plain) (Samuel et al., 2002; Utomo et al., 1995). Daerah aliran Sungai Musi di Sumatera Selatan merupakan ekosistem yang berperan penting sebagai sentra produksi ikan, sumber mata pencaharian penduduk serta penyedia protein hewani berupa ikan bagi masyarakat. Daerah aliran Sungai Musi di Sumatera Selatan telah lama dimanfaatkan oleh masyarakat untuk perikanan tangkap dan beberapa bagian telah menunjukkan penurunan hasil tangkapan. Penurunan ini disebabkan oleh penangkapan yang intensif dan juga perubahan atau hilang habitat ikan tersebut akibat perubahan fungsi lahan.

Keragaman jenis ikan yang tinggi disertai dinamika perairan di rawa banjiran mengakibatkan kegiatan penangkapan ikan di perairan rawa banjiran mempunyai intensitas yang tinggi pula. Nelayan tradisional telah memanfaatkan pola tingkah laku ikan dalam kegiatan penangkapan, antara lain menggunakan perangkap dan pagar yang dipasang memotong jalur pergerakkan ikan, menggunakan karakat dari jaring (seine) untuk menangkap ikan di badan air yang tertutup dengan pagar bambu dari empang (barrier) (Gaffar \& Utomo, 1987).
Beberapa faktor yang mempengaruhi pemilihan alat tangkap ketika melakukan penangkapan (Welcome, 2001; Arifin, 1978) adalah:

1. Musim; Musim sangat mempengaruhi pemilihan aktivitas penangkapan. Sebagai contoh penangkapan dengan sistem ngesar pada musim kemarau dengan menggunakan arat atau kerakat yang terbuat dari jaring (seine) yang digunakan untuk menggiring ikan masuk ke tempat yang lebih dangkal sehingga mudah ditangkap.

2. Keuangan nelayan; Pada umumnya nelayan yang melakukan penangkapan dengan sistem ngesar merupakan nelayan pemilik modal besar, karena alat yang digunakan dan biaya operasional cukup tinggi. Sedangkan bengkirai (pot trap) terbuat dari bambu, jaring gill net yang terbuat dari nylon, sehingga biaya tidak mahal, sering digunakan oleh nelayan kecil.

3. Kondisi lokasi penangkapan; Lahan rawa banyak ditumbuhi oleh tumbuhan air seperti Graminnae. Penangkapan di lahan rawa dan sungai secara intensif dilakukan ketika air tidak terlalu tinggi dan saat air surut. Alat yang sering digunakan di perairan lebak lebung dan sungai pada umumnya tergantung pada kondisi saat penangkapan. Untuk daerah rawa lebak (flood plain) dengan genangan air yang tidak begitu luas dan perairan sungai pada saat air surut menggunakan alat arat atau kerakat terbuat dari jaring (seine) sebagai alat bantu untuk menggiring ikan dan pagar bambu atau empang (barrier) untuk menjebak ikan. 
4. Ikan sasaran; Setiap alat tangkap punya sasaran ikan yang akan ditangkap. Contoh untuk ikan snake head atau gabus (Channa sp.) dan baung (Mystus nemurus) yang berukuran besar pada umumnya penangkapan menggunakan pancing (tajur atau rawai) dengan ukuran mata pancing 5 sampai dengan 8 . Sedangkan ngesar mempunyai sasaran multi spesies (bermacam-macam jenis ikan).

Menurut Gaffar et al. (2004), ikan yang dominan di peroleh dengan menggunakan berbagai alat tangkap di perairan rawa banjiran daerah aliran Sungai Musi adalah ikan gabus. Hal ini, kemungkinan karena ikan gabus merupakan ikan rawa yang mampu beradaptasi dengan perubahan kondisi lingkungan rawa yang ekstrim sehingga populasi tetap terjaga. Jenis alat tangkap juga sangat berpengaruh terhadap jenis ikan yang diperoleh, misal tajur dan rawai yang ukuran mata pancing 5 sampai dengan 8 dipasang pada daerah rawa lebak baik ketika air surut maupun pasang dengan tujuan untuk menangkap ikan berukuran besar seperti ikan gabus dan toman.

Penggunaan alat tangkap oleh nelayan juga tergantung pada kondisi lingkungan dan musim. Alat tangkap jaring, tajur, pancing (tajur dan rawai) digunakan setiap saat tanpa mengenal musim. Tajur dipasang pada sore hari kemudian diperiksa pada pagi hari, sedangkan hempang pada umumnya digunakan pada musim kemarau atau ketika air surut, bengkirai dioperasikan pada musim banjir di rawa lebak dan corong pada anak sungai pada musim banjir (air naik). Produksi ikan di daerah rawa banjiran tidak stabil dan cenderung menurun setiap tahun yang disebabkan oleh beberapa faktor iklim, intensitas penangkapan yang tinggi terutama pada musim kemarau, pendangkalan yang disebabkan gulma air dan erosi akibat penebangan kayu pada hutan rawang (Arifin \& Ondara, 1981).

\section{PENANGKAPAN DENGAN SISTEM “NGESAR”}

Ngesar adalah kegiatan untuk menangkap ikan yang telah terkonsentrasi baik di sungai maupun di lebak (rawa) pada puncak musim kemarau atau surut dan arus tenang dengan menggunakan kerakat (waring) dan rumah ikan yakni sejenis kurungan (fence system). Ngesar merupakan kegiatan penangkapan yang efektif baik jenis ikan yang tertangkap maupun jumlah hasil tangkapan. Prinsip penangkapan dengan sistem ngesar adalah menggiring dan mendesak ikan agar semua masuk ke dalam kurungan yang oleh masyarakat setempat disebut rumah ikan, lalu ikan diambil dengan menggunakan seser sedikit demi sedikit sampai dengan ikan habis. Berdasarkan pada studi kasus di Kabupaten Ogan Komering Ilir, Kabupaten Musi Banyuasin, dan Kabupaten Banyuasin kegiatan ngesar, membuat rumah ikan dan penetak. Rumah ikan adalah kurungan yang terbuat dari anyaman bambu. Penetak adalah semacam pagar yang terbuat dari bambu yang dimaksudkan agar ikan yang digiring tertahan oleh penetak tersebut. Menggiring dan mendesak ikan; penggiringan dilakukan oleh beberapa orang. Jika ikan yang digiring tersebut telah masuk ke dalam rumah ikan yang dimaksud lalu dinding bagian hilir segera ditutup rapat sehingga terbentuk kurungan. Penangkapan ikan yang telah terkurung dalam rumah ikan tersebut diambil sedikit demi sedikit dengan membentuk jaring menjadi lingkaran kecil di tempat yang telah ditentukan (Arifin, 1978; Arifin \& Ondara, 1981; Said et al. 2004).

Nelayan yang ingin melakukan ngesar di suatu perairan menang dalam pelelangan perairan yang di sebut lelang lebak lebung. Lelang lebak lebung ini dilaksanakan oleh pemerintah marga (kelurahan) dengan tujuan mengatur pembagian hak penangkap ikan agar tidak terjadi perselisihan.

Pemenang lelang adalah penawar tertinggi. Nelayan yang ingin mengikuti lelang lebak lebung tersebut memenuhi syarat tertentu:

1. Peserta tidak mempunyai hutang pada pemerintah marga.

2. Pembayaran dilakukan secara tunai.

3. Jika penawar tertinggi tidak mampu membayar sesuai dengan harga penawaran, maka kemenangan diberikan pada penawar tertinggi ke2. Jika penawar ke-2 juga tidak mampu membayar, maka dilakukan lelang ulang. Jika terdapat selisih harga dengan lelang pertama, maka selisih itu dibayar oleh penawar tertinggi lalang pertama.

Kegitan penangkapan yang disebut dengan ngesar (active seine) di perairan umum daerah aliran Sungai Musi bagian tengah terjadi pada musim kemarau bulan Juli dan Agustus. Hasil tertinggi di dapatkan dari hasil ngesar alat bantu atau empang dan arat di rawa banjiran mencapai $40 \%$ dari total hasil tangkapan (Gaffar et al., 2005). Hasil tangkapan pada bulan Agustus 2005 berkisar $\pm 3.985 \mathrm{~kg}$ sedangkan pada bulan Juli 2005 berkisar $\pm 3.294 \mathrm{~kg}$. Hal ini, kemungkinan disebabkan pada bulan Agustus air lebih surut sehingga penangkapan menjadi lebih efesien dan pada bulan tersebut merupakan puncak penangkapan. Produksi hasil tangkapan dan keanekaragaman jenis ikan yang tinggi ini 
kemungkinan karena perairan ini termasuk perairan subur karena dasar perairan berupa lumpur bercampur humus dari akar, batang serta seresah daun tanaman semak yang lapuk akibat proses dekomposisi.

Kegiatan penangkapan sistem ngesar (active seine) di daerah aliran Sungai Musi Kabupaten Musi Banyuasin dapat dilihat pada Gambar 1 sampai dengan 3 dan komposisi hasil tangkapan di Sungai Kesambi dan Sungai Selarai tercantum pada Tabel 1.

Berdasarkan pada Tabel 1 di atas, rawa banjiran di daerah Kesambi dan Selarai mempunyai keanekaragaman jenis ikan yang tinggi. Di Sungai Kesambi didapatkan sekitar 28 jenis ikan dan di Sungai Selarai sekitar 22 jenis. Ikan-ikan tersebut merupakan jenis ikan konsumsi ekonomis tinggi. Tangkapan ikan di ke-2 daerah berdasarkan pada prosen bobot didominasi oleh ikan baung (Mystus nemurus), gabus (Channa striata), lais (Cryptopterus sp.), sapil (Heleostoma sp.), tembakang (Heleostoma temminckii), dan toman (Channa micropeltes). Pada penangkapan bulan Agustus di daerah Sungai Kesambi tidak didapatkan jenis ikan sarko (Channa lucius), si hitam (Labeo chryssophekadion), dan tebengalan (Puntius bulu) dan pada daerah penangkapan Sungai Selarai ikan jenis damaian (Thynnichthys pollylepis), seberas (Cynoglossus sp.), lele (Clarias melanoderma), sarko (Channa lucius), tilan (Masteccembulus unicolor), dan tebengalan (Puntius bulu) juga tidak didapatkan. Untuk jenis ikan sarko hasil tangkapan rendah hal ini kemungkinan disebabkan oleh keberadaannya di perairan tersebut sudah mulai langka. Berdasarkan pada penelitian Said et al (2004) ikan hasil tangkapan nelayan jenis ikan sarko hanya $0,5 \%$ dari total tangkapan jenis kelompok gabus (marga Channa) di daerah aliran Sungai Musi.

Tabel 1.

Komposisi hasil tangkapan berdasarkan pada persentase bobot dengan penangkapan sistem ngesar

\begin{tabular}{|c|c|c|c|c|c|}
\hline \multirow{3}{*}{ Jenis ikan } & \multirow{3}{*}{ Nama ilmiah } & \multicolumn{4}{|c|}{ Lokasi penangkapan } \\
\hline & & \multicolumn{2}{|c|}{ Kesambi } & \multicolumn{2}{|c|}{ Selarai } \\
\hline & & Juli & Agustus & Juli & Agustus \\
\hline Baung & Mystus nemurus & 11,4 & 7,7 & 15,4 & 9,1 \\
\hline Betutu & Oxyeleotria marmorata & 0,2 & 0,7 & 0,4 & 0,4 \\
\hline Beringit & Mystus nigricep & 0,9 & 1,6 & 1,6 & 1,7 \\
\hline Betok & Anabas testudineus & 0,3 & 0,4 & 0,2 & 0,6 \\
\hline Bujuk & Channa cyanospilos & 2,2 & 10,3 & 3,9 & 12,9 \\
\hline Damaian & Thynnichthys pollylepis & 1,2 & 0,1 & - & - \\
\hline Gabus & Channa striata & 10,8 & 16,6 & 15,3 & 16,6 \\
\hline Juaro & Pangasius polyuranodon & 2,8 & 0,9 & 2,1 & 1,1 \\
\hline Kepras & Puntius sp. & 0,8 & 1,1 & 0,7 & 0,7 \\
\hline Lampam & Burbodes schwanefeldi & 0,5 & 0,9 & 0,4 & 1,9 \\
\hline Lais & Cryptopterus sp. & 12,2 & 16,6 & 14,5 & 11,5 \\
\hline Lele & Clarias melanoderma & 4,4 & 0,4 & - & - \\
\hline Lundu & Mystus gulio & 0,9 & 1,3 & 0,6 & 0,2 \\
\hline Palau & Osteochilus haselti & 1,8 & 0,9 & 1,6 & 0,8 \\
\hline Sapil & Helostoma temminckii & 13,6 & 12,2 & 12,5 & 10,8 \\
\hline Seberas & Cynoglossus sp. & 1,5 & 0,4 & - & - \\
\hline Selincah & Polycanthus hasselti & 0,2 & 0,4 & 0,6 & 0,3 \\
\hline Sepat mato merah & Trichogaster tricopterrus & 0,6 & 1,4 & 0,3 & 0,5 \\
\hline Sepat siam & Trichogaster pectoralis & 1,3 & 0,7 & 0,9 & 0,8 \\
\hline Sepatung & Pristolepis fasciata & 2,5 & 0,2 & 2 & 1,3 \\
\hline Sarko & Channa lucius & 0,2 & - & - & - \\
\hline Sihitam & Labeo chryssophekadion & 0,4 & - & 0,8 & 0,8 \\
\hline Tара & Wallago leeri & 1,3 & 2,9 & 2,2 & 2,5 \\
\hline Tembakang & Helostoma temminckii & 12,4 & 13,9 & 18,4 & 12,4 \\
\hline Tilan & Masteccembulus unicolor & 0,3 & 0,2 & - & - \\
\hline Toman & Channa micropeltes & 7,8 & 7,6 & 5 & 10,3 \\
\hline Tebengalan & Puntius bulu & 0,2 & - & & - \\
\hline Udang Galah & Macrobrachium rosenbergii & 0,5 & 0,3 & 0,5 & 0,5 \\
\hline
\end{tabular}




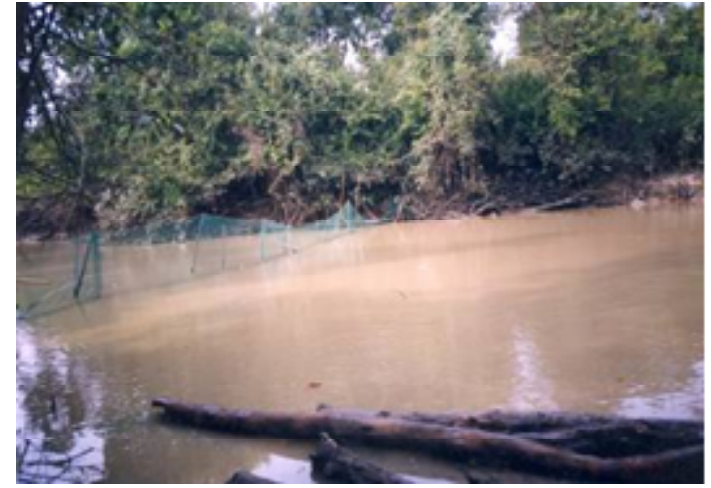

Gambar 1. Lokasi dan alat tangkap yang digunakan saat ngesar.

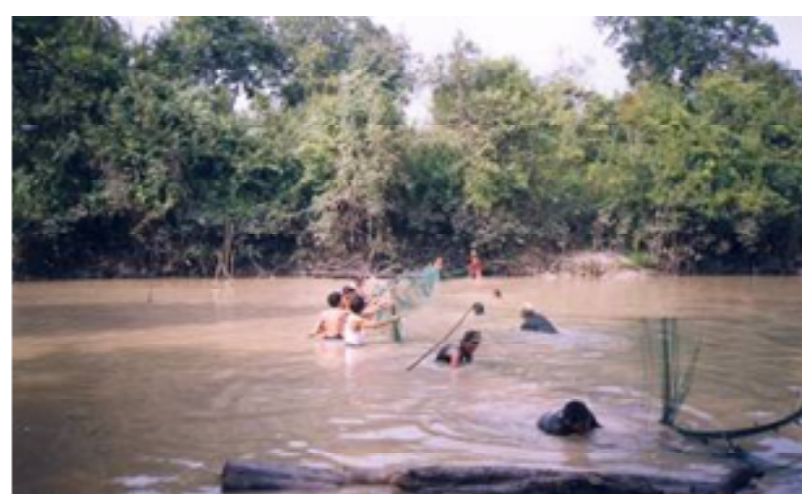

Gambar 2. Aktivitas penangkapan dengan sistem ngesar.

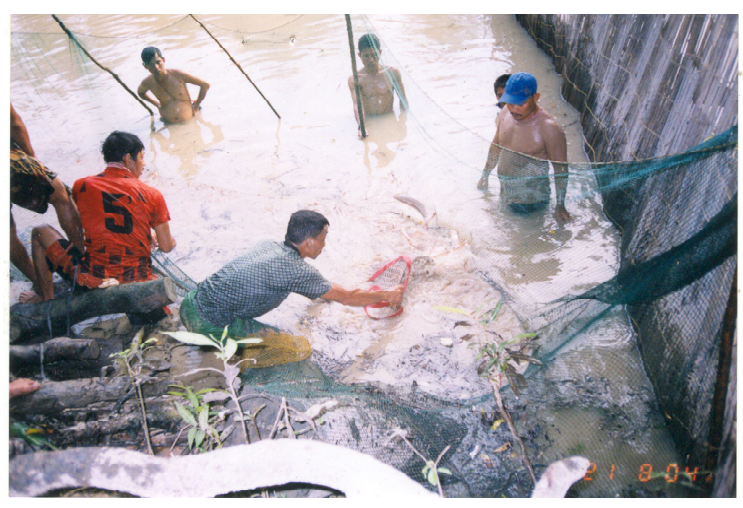

Gambar 3. Pengambilan hasil tangkapan ngesar dengan seser.

Menurut Arifin, (1978) Arifin \& Ondara(1981), hasil tangkapan dengan cara ngesar memperlihatkan penurunan jumlah hasil tangkapan setiap tahun. Hal ini, kemungkinan disebabkan oleh intensitas penangkapan yang tinggi terutama ketika musim kemarau. Hasil tangkapan pada tahun 1976 di daerah lubuk lampam mencapai $87.760,5 \mathrm{~kg}$ atau sekitar $0,26 \%$ dari produksi total penangkapan di perairan umum Indonesia dan pada tahun 1980 turun menjadi $28.429,3 \mathrm{~kg}$. Tinggi hasil tangkapan pada tahun 1976 ini karena pada tahun-tahun sebelumnya tidak terjadi kemarau panjang dan air tidak terlalu surut sehingga ngesar tidak dapat dilakukan. Hal ini, menyebabkan sebagian besar jenis ikan sempat untuk tumbuh dan berkembang. Pada tahun 1977 terjadi lagi musim kemarau panjang sehingga ngesar dapat kembali dilakukan tetapi hasil yang didapat hanya 45.892,6 $\mathrm{kg}$ atau $52,3 \%$ dari hasil tangkapan tahun 1976 atau sekitar $0,11 \%$ dari produksi tangkapan perairan umum di Sumatera Selatan (Arifin \& Ondara, 1981; Zain, 1981).

Hasil tangkapan sistem ngesar didapatkan banyak spesies, beberapa contoh jenis ikan yang tertangkap dapat dilihat pada Gambar 4. 


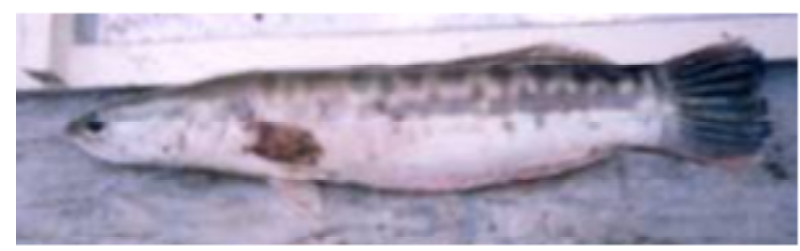

Toman (Channa micropeltes)

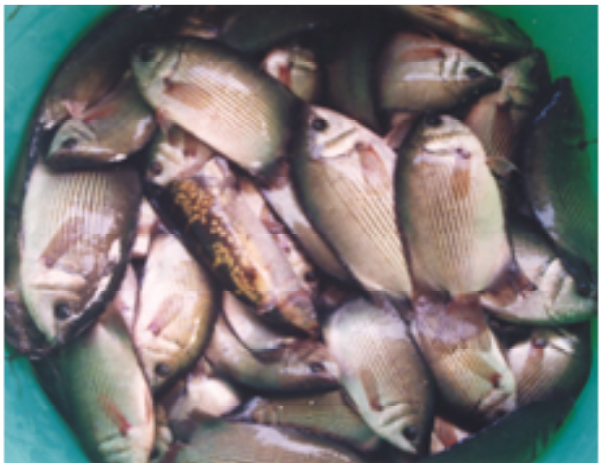

Tembakang (Helostoma temminckii)

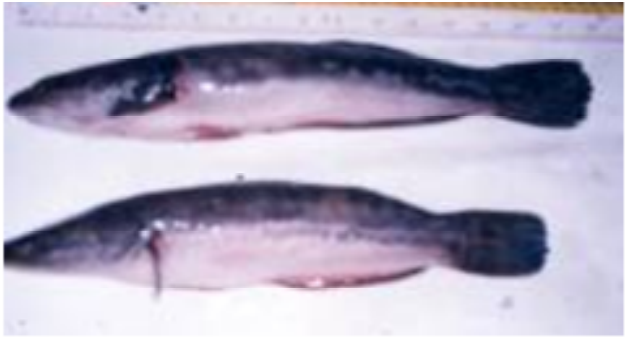

Gabus (Channa striata)

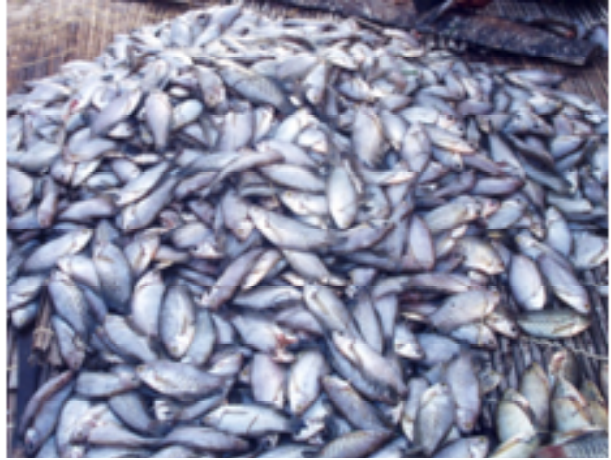

Ikan sepat siam (Trichogaster pectoralis)

Gambar 4. Beberapa jenis ikan yang tertangkap dengan Sistem "Ngesar".

\section{KESIMPULAN}

Kegiatan pengangkapan sistem ngesar (active seine) dilakukan pada saat musim kemarau setempat. Ngesar termasuk alat tangkap yang tidak selektif dapat menangkap ikan berbagai jenis dan berbagai ukuran. Hasil tangkapan dengan cara ngesar dari tahun ke tahun mengalami penurunan sebagai akibat dari penangkapan yang intensif. Perubahan habitat terjadi karena pendangkalan yang disebabkan gulma air dan erosi akibat penebangan kayu pada hutan rawang.

\section{PERSANTUNAN}

Kegiatan dari hasil riset bioekologi ikan marga Channa untuk pelestarian dan pengembangan perikanan perairan umum di daerah aliran Sungai Musi, T. A. 2004, di Balai Riset Perikanan Perairan UmumMariana, Palembang.

\section{DAFTAR PUSTAKA}

Arifin, Z. 1978, Beberapa aspek tentang penangkapan ikan di perairan lubuk lampam. Simposium Modernisasi Perikanan Rakyat. Jakarta. 27-30 Juni 1997.
Arifin, Z. \& Ondara. 1981. Pengelolaan perikanan di perairan lubuk lampam. Prosiding Seminar Perikanan Perairan Umum.

Gaffar, A. K. \& A. D. Utomo. 1987. Perikanan perairan umum di daerah aliran Sungai Musi. Makalah Siposium Perikanan Indonesia II. Ujung Pandang 2-3 Desember 1987.

Gaffar, A. K., K. Fatah, \& T. Hidayah. 2004. Riset kegiatan perikanan di perairan rawa banjiran Sungai Musi. Laporan Teknis Tahun 2004. Balai Riset Perikanan Perairan Umum. Palembang.

Gaffar, A. K., K. Fatah, \& T. Hidayah. 2005. Riset kegiatan perikanan di perairan rawa banjiran Sungai Musi. Laporan Teknis Tahun 2005. Balai Riset Perikanan Perairan Umum. Palembang.

Said, A., A. K. Gaffar, E. Dharyati, \& D. Muthmainah. 2004. Riset biologi ikan marga Channa (Gabusgabusa) di perairan umum daerah aliran Sungai Musi Sumatera Selatan. Laporan Teknis Balai Riset Perikanan Perairan Umum. Palembang.

Samuel, S. Adjie, \& Subagja. 2002. Inventarisasi dan distribusi biota serta karakteristik habitat Sungai 
Musi. Laporan Teknis Balai Riset Perikanan Perairan Umum. Palembang.

Utomo, A. D., Z. A. Nasution, \& S. Adjie. 1995. Pemanfaatan berbagai tipe ekosistem daerah aliran sungai melalui penerapan teknologi budi daya ikan tepat guna. Kumpulan Makalah Seminar Penyusunan, Pengolahan, dan Evaluasi Hasil Penelitian Perikanan di Perairan Umum. Palembang 27-28 Pebruari 1994. Sub Balai
Penelitian Perikanan Air Tawar Palembang. Pusat Penelitian dan Pengembangan Perikanan. Badan Penelitian pengembangan Pertanian.

Welcome, R. I. 2001. Inland fisheries: Ecology and management. Blackwell Science. U. K.

Zain, I. B. 1981. Status perikanan perairan umum di Sumatera Selatan. Prosiding Seminar Perikanan Perairan Umum. 